\title{
CONVERSION OF VILLAGE DRUWE RIGHTS BECAME PROPRIETARY RIGHTS ACCORDING TO ARTICLE II PROVISIONS ON THE CONVERSION OF AGRARIAN LAWS (UUPA)
}

\author{
Nonik Latifah \\ Universitas Brawijaya \\ noniklatifah5@gmail.com
}

\begin{abstract}
Bali Provincial Regulation Number 3 of 2001 which has been amended by Bali Provincial Regulation number 3 of 2003 concerning Desa Pakraman article 9 paragraph (5) explicitly states that land owned by Pakraman village of Bali cannot be certified in the personal name and Decree of the Minister of Agrarian Affairs and Spatial Planning / Head of National Land Agency Number 276 / Kep19. 2 / X / 2017 concerning the appointment of Pakraman Village in the province of Bali as the subject of communal ownership rights designates the pakraman village as the subject of joint ownership rights. This brings polemic related to the existence of the village Druwe's land rights. Then the focus of this research is whether the conversion of Druwe Village Rights Into Property Rights According to Article II Provisions for Conversion of the Basic Agrarian Law (UUPA) is in accordance with the law. How should the conversion of Druwe Desa rights to land rights according to the UUPA as for the research methods used Normative law research (normative law research). The approach used. Statute Approach and Historical Approach. The results of this study are found. Conversion of Village Druwe Rights to Property Rights According to Article II, the Conversion Provisions for the Basic Agrarian Law (UUPA) are not in accordance with the law, because the rights of village druwe with ownership rights do not have in common or similarities either with respect to the subject of the holder of his land rights or the authority of the holder of his right, so that conversions cannot be carried out.
\end{abstract}

Keywords: Agrarian law, Civil law, Conversion, Customary law, Druwe Desa.

\section{A. INTRODUCTION}

In connection with the provisions of Article 16 jo. Article 53 of Law Number 5 of 1960 (UUPA), the types of land rights after the birth of LoGA are grouped into 3 (three), namely. ${ }^{1}$ :

1 Article 16 jo. Article 53 of Law Number 5 of 1960 (LoGA). Specifically mentions land rights. Namely: Permanent land rights, land rights that will be determined by law and temporary land rights.

\begin{tabular}{|c|c|c|}
\hline $\begin{array}{l}\text { ine } \\
\text { id } \\
\text { s }\end{array}$ & $\begin{array}{l}\text { Land rights } \\
\text { will be } \\
\text { determined } \\
\text { by law }\end{array}$ & $\begin{array}{r}\text { ra } \\
\text { la } \\
\text { rig }\end{array}$ \\
\hline $\begin{array}{l}\text { that is, } \\
\text { land rights } \\
\text { that will } \\
\text { remain as } \\
\text { long as } \\
\text { UUPA is in } \\
\text { effect. The } \\
\text { types of }\end{array}$ & $\begin{array}{l}\text { the intention } \\
\text { is land rights } \\
\text { that will be } \\
\text { born later, } \\
\text { which will be } \\
\text { determined } \\
\text { by law. The } \\
\text { land rights }\end{array}$ & $\begin{array}{l}\text { are } \\
\text { tempor } \\
\text { ary in } \\
\text { nature, }\end{array}$ \\
\hline
\end{tabular}




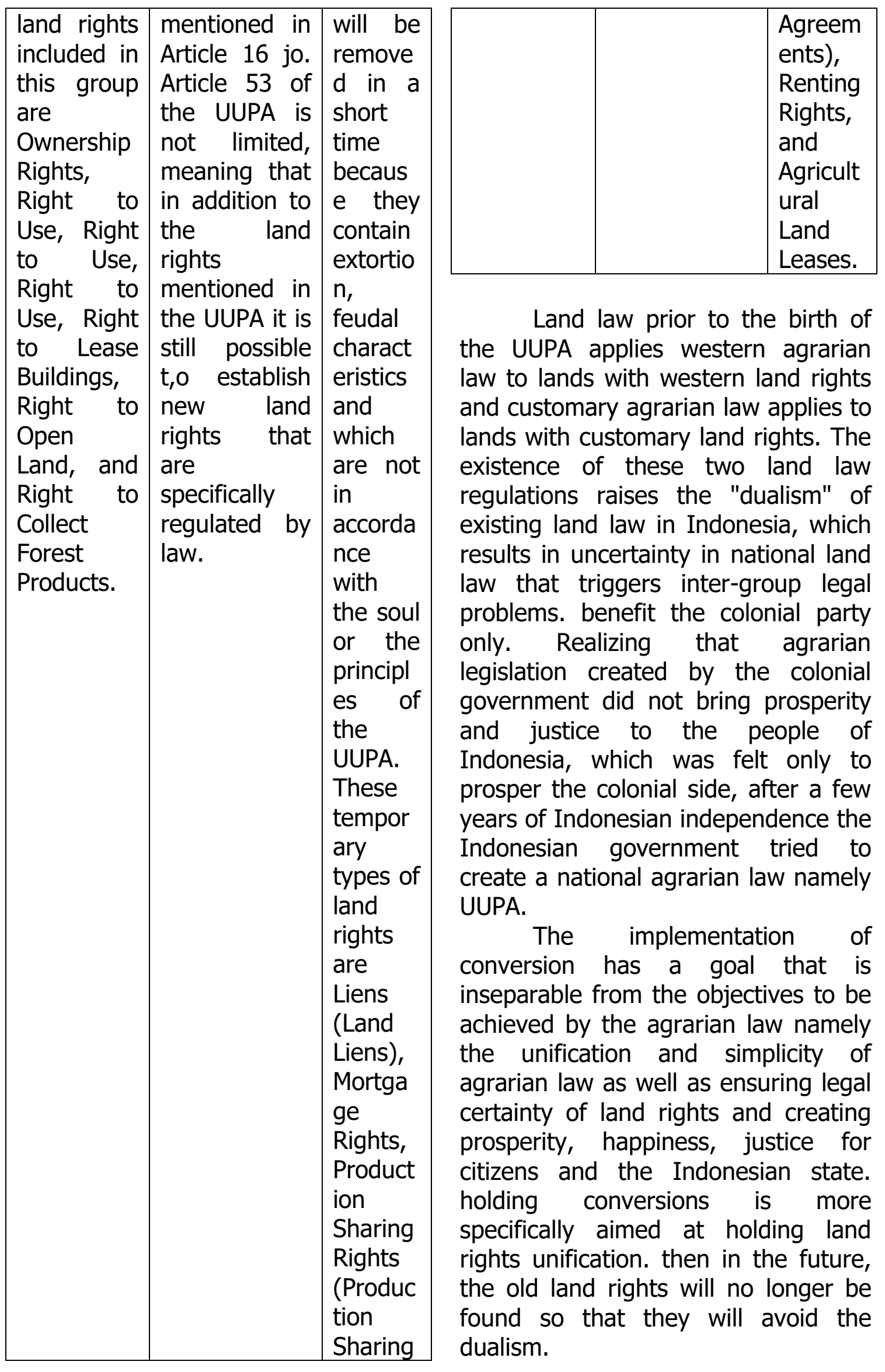


The subject of property rights as stipulated in UUPA article 21 paragraph 1 and paragraph 2 is an individual who is entitled to the Government of the Republic of Indonesia and Law No. 38, and has been established by the Government of Law No. 38 of 19/2003. 1963-61). In article 1 , it is said that the legal entities that have the rights to belong to the land of God: state banks, cooperative bodies of government, religious institutions and social institutions.. ${ }^{2}$

Based on the considerations that the law can be given to the economy, it is only in the economic importance of the country. With such a lot of individuals and even the law does not fulfill the right as a subject of property does not even have the right to have property.

The Second chapter of UUPA is about the Terms of Conversion is a legal basis governing the conversion of both the right to western land and the right of Indonesia or the right to customary land. then regulated in the conversion implementation rules. in this study the authors put the limitation of research on the discussion of Indonesian rights or land rights only, that is especially regarding the conversion of village druwe rights into property rights that are contained in the provisions of conversion of agrarian law article 2 paragraph 1 , because basically the rights of village druwe are rights belongs to the condition if the legal subject meets the requirements as stipulated in article 21 of the agrarian law.

2 Arba, Hukum Agraria indonesia, Jakarta, Sinar grafika, 20017, page. 98
Druwe village rights are rights to land owned or controlled by indigenous villages obtained from the purchase of indigenous peoples or other businesses intended for the interests of indigenous peoples. which in the Balinese community is known as Druwe Desa Pakraman Bali based on Bali Province Regional Regulation number 3 of 2003 concerning Desa Pakraman. The village village of Adat Village in the Province of Bali.

Especially for the past years, since 1986 through a letter of ministerial decree in the country SK number. 556 / DJA / 1986 concerning the appointment of a temple as a religious legal entity that can have ownership rights in the name of the temple, with consideration for granting legal certainty in the form of a certificate and in accordance with the teachings of the Hindu religion, a temple with "Palemahan" land is an inseparable unity of functions. Likewise, the Druwe land of Pakraman village is inseparable..

The continued action to guarantee the certainty of the law is also stated in article 19 paragraph 1 of the agrarian law which determines to guarantee legal capacity by the government in the future, the preaching of the entire territory of the Republic of Indonesia. Even though this regulation was followed up with the enactment of the Government of the Republic of Indonesia Government Regulation Number 24 in 1997 concerning the Government Registration, (LN. 1997-59, TLN.3696). Also called PP No. 24 years $1997 .^{3}$

3 Government Regulation of the Republic of Indonesia Number 24 in 1997 concerning the 
It is related to the authorization of the transfer of authority to the Swatantra Region and authorized to the customary law community. customary law communities in each region have different mention. The Customary Law Community Unit in Bali is called Pakraman, the regulation regarding the Pakraman village is regulated in the 2001 Provincial Regulations No. 29 Series D Number 29). ${ }^{4}$

Then Regional Regulation No. 3 of 2001 occurred in the Regional Regulation of the Province of Bali Number 3 in 2003 concerning the Provincial Regulations of the Province of Bali in the Province of Bali, No. 3, 2003 subsequently referred to as Perda Province Bali No. 3 of 2003).

The definition of Desa Pakraman regulated in Article 1 number 4 of the Provincial Regulation of the Province of Bali Number 3 in 2001. Article 9 (5) Province of Bali Province Regulation No. 3 In 2001, it was written that "the village's land and land have not been owned by the villagers". Specifically, the government regulation does not include the right of the village, but the village can be registered only in the land of "Laba Pura". And the government regulation has still not been able to accommodate to guarantee the legality of the Druwe Rights.

Customary Rights as a right has the concept of shared ownership

State Administration, (LN. 1997-59, TLN.3696). Also called PP No. 24 years 1997.

4 In the Province of B Provinsili Province Number 3 in 2001, the Provincial Government of the Province of B 3li Province in 2001 Number 29, Series 29 , Number 29 , was subsequently called the Regional Regulation of the Province of Báli No. 3, 2001). (communal rights), which has authority, to use, as well as to regulate in the form of the management of the land, the use, the use, law and the use of the law. This relationship shows the nature of people's autonomy at all times. Join with the village villagers in the first leg of the law to get the recognition of the existence of a number of years ago. From the preamble in the common sense that the conflict is normal, which is related to the conversion to the province in 2012 on the number of provinces in the province (No. 5). In the Bali Province number 3 in 2003 concerning the village of Pâkrām. It has always been mentioned that the property of the villagers cannot be certified in terms of personal status. Because of that, there will be a lot of those who have the law on land ownership (communal), such as the law, after being converted into law, after being converted into law.

The author uses a normative legal research methodology (normalized in research), research is carried out by inventing and analyzing positive law in the form of, the legalities, the legal doctrines, and the principles of law in the form of positive law, the legalities, the legal doctrine and the legal principles in the area. ${ }^{5}$ The research was carried out to obtain the number of people who made the right according to the Decree of the Republic of Indonesia prior to the conversion to the law, namely the author, namely the

5 Anis Mashdurohatun, Intellectual Property Protection of Indigenous Peoples in Indonesia: Quo Vadis?, Sociological Jurisprudence Journal, Volume 3; Issue 1; 2020, Page.2 
conversion of the law to the law. according to the UUPA? In the research the authors analyzed the Regulation of the Regulations relating to the conversion of the Druwe village into property rights according to the provisions in Article 20 of the UUPA.

\section{B. DISCUSSION}

\section{Conversion of Village Druwe Rights to Property Rights According to Article II the Conversion Provisions on the Basic Agrarian Law (UUPA) are in accordance with the law.}

Ownership of land rights associated with the Druwe Village Right is the right to land owned or controlled by the adat village or other businesses intended for the interests of the adat community. To realize legal certainty, simplicity and unification in the Agrarian Law, the conversion of old land rights, both western land rights and customary land rights, becomes new land rights according to the Agrarian Law. the agrarian main law distinguishes land tenure rights into two groups, namely land rights and land security rights. Land rights that determine the land tenure system can be divided into 2 categories, i.e.. ${ }^{6}$

a. All that is obtained directly from the country (called primary)

b. All those who hold the rights are only on the basis

6 Boedi Harsono, Hukum Agraria Indonesia, Jilid I, Bagian I, Jambatan, Jakarta, 2008, page. of the agreement on the date (called the secondary date).

in principle, the conversion can be carried out on land rights that have similarities or similarities between the new land rights on the subject of the holder of the right and the authority of the subject of the holder of the land rights. if there are no similarities or similarities between the new land rights, the conversion cannot be carried out.

Based on the concept of conversion, the conversion of land rights of Druwe Desa into ownership rights as regulated in Article 20 of the agrarian law must be seen in the subject of rights holders and authorities of the rights holders of the two land rights. as explained in the previous chapter the village druwe in this study is the pakraman bali village druwe. The villagers based on the stipulations in the article 1 (4) of the Government of the Province of $B$ Bli No. 3 IN 2001, which was changed by the Government in the Province of BALI No. 32003 About the Village Design? From the stipulations in the

7 Article 1 (4) Department of Agriculture in B Bli Province No. 3 Tahun 2001 yang telah diubah dengan Peraturan daerah Bali Province 3 Tahun 2003 Tentang Desa Pakraman adalah kesatuan masyarakat adat provincial law Bali yang mempunyai satu kesatuan tradisi dan tata krama pergaulan masyarakat life secara hereditary Hindu umat dalam ikatan kahyangan tiga atau kahyangan desa who have a certain territory and only the power of their own and to take care of their own home.. 
article, it is known that the subjects of the people are residents of the village. Article 1 or 1 Minister of the Republic of Indonesia Regulation Number 52 in 2014 (State of the Republic of Indonesia in 2014: 951) Concerning the Guidelines for Protection and Protection of the Poor Laws enforce the rule of law on the law. ${ }^{8}$

the customary law community based on Article 1 of the BAli Province Regional Regulation is divided into 4 (four) types, as follows:

a. Banjar Pakraman is a group of people who are part of the Pakraman village (article 5);

b. "Krama Desa" or "Krama Banjar" are those who forged villages in and lived in villages in the village area / "Banjar Pakraman" or another place in the village of Pakraman. (article 6);

c. Krama

pangempong/

Pangemong is a krama desa pakraman/krama banjar pakraman that has In the end, it will be true to the people who took place in the area of the activity and to the extent

8 Article 1 (4) Department of Agriculture in B Bli Province No. 3 Tahun 2001 yang telah diubah dengan Peraturan daerah Bali Province 3 Tahun 2003 Tentang Desa Pakraman adalah kesatuan masyarakat adat provincial law Bali yang mempunyai satu kesatuan tradisi dan tata krama pergaulan masyarakat life secara hereditary Hindu umat dalam ikatan kahyangan tiga atau kahyangan desa who have A Certain territory and only the power of their own and to take care of their own home. of the maintenance of the customary activities. (article 7);

d. Krama penyungsung is a krama desa pakraman/ krama banjar pakraman that has the intention of the fortune and will participate in the maintenance of the event and the annihilation of the activities of the up to the end. (article 8);

In the authorization and the use of the village, it was carried out collectively or only in accordance with the law, in fact, at the same time. The authority of the law is in the villages of the people, the residents of the village, the village residents, the people of the village, the people of the village, the people of the village. and against the land it was offered to sell or memadanjan of village villages at a time but nevertheless.

land rights as stipulated in article 20 of the agrarian law are rights that have a hereditary, strongest, and fulfilled nature that people can have land rights. which can have ownership rights based on article 21 of the Agrarian Law paragraphs (1) and (2) are Indonesian citizens and legal entities appointed by the government, namely state banks, government cooperatives, religious bodies and social bodies based on government regulations number 38 of 1963 concerning legal entities that can have 
ownership rights over land. based on the provisions of these articles, the subject of ownership is::

a. individuals who are Indonesian citizens

b. state banks, government cooperatives, religious bodies and social agencies appointed by the government.

Furthermore, village designation as a subject of ownership is communicated. After the village has been appointed as a subject of ownership in communion, the province has the obligation to do so in the province.

The land registration begins with a communal request. the inauguration refers to the Regulation of the Minister of Agrarian Affairs and Spatial Planning or Head of the National Land Agency Number 10 of 2016 in Article 4 paragraph 1 , the requirements are confirmed in their communal rights. these requirements can also be found in dictuym one of the Decree of the Minister of Agrarian / Head of the National Land Agency concerning the Designation of the Village Land Subjects, namely: Konversi bekas hak-hak atas tanah merupakan salah satu instrumen untuk memenuhi asas unifikasi hukum melalui Undang-Undang Nomor 5 Tahun 1960. Peraturan Menteri Pertanahan dan Agraria (PMPA) Nomor 2 Tahun 1962 mengatur ketentuan mengenai penegasan konversi dan pendaftaran bekas hak-hak Indonesia atas tanah secara normatif.

It was also known before the issuance of the UUPA that I was in the midst of a legal agreement in Indonesia (du'ism). That is sourced from the law and is called the law and which is sourced from the law is called the law. With the passage of the general law, the nature of the law (UUPA) will be made only before the date. To be able to enter into the UUPA system, the system is completed by passing the conversion agency.

As for the basis of land rights that existed before the entry into force of the agrarian law of September 24, 1960, was the second part of the agrarian law "Regarding the terms of the conversion which consisted of the sectarian elements of the first Pates to the nine Parties".

Especially for the conversion of lands subject to customary law and the like regulated in Article II, article IV and article VII of the provisions of conversion, in addition to the implementation of the conversion referred to by the LoGA confirmed by the issuance of the Minister of Agriculture and Agrarian Regulation number 2 of 1962 and Minister of Home Affairs Decree Number 26 / DDA / 1970 , which is about affirming 
the conversion and registration of former land rights.

Regarding pakraman village land or pakraman village land based on the provisions of article 9 paragraph 5 Regional Regulation of the Province of Bali Number 3 of 2001 which has been amended by Regional Regulation of the Province of Bali number 3 of 2003 concerning pakraman village, stipulates that land owned by pakraman village cannot be certified in the personal name . based on the decree of the minister of agrarian and spatial planning / Head of the National Land Agency Number 276 / KEP-19.2 / X / 2017 Regarding the Design of the Land in the Province of Bāli As a Subject to the Right to Respect (Communities) in the area in the area of the Regency of West Sumatra. The term of the village designation as a legal subject to the right of the people (communal) is about as long as it is based on the government claim and a certain amount of time.

Druwe land in Pakraman village, if related to the provisions of the agrarian main article article 4 paragraph $1,{ }^{9}$ then the pakraman village

9 Pasal 4 ayat (1) Undang-undang 5 Tahun 1960 Tentang Peraturan Dasar Pokol main menyenutkan Agraria bahwa: "Atas dasar hak menguasai dari Negara sebagi yang dimaksud dalam pasal 2 ditentukan macam-macam hak atas tanah permukaan earth, yang called tanah , which can be given to and possessed by people, even by themselves and even with other people and with the law ". cannot have ownership rights to the land, because those who can have ownership rights to the land, because the only persons individually or jointly can own ownership of the land and the legal entity appointed by the government and pakraman village is not a legal entity can be subject to legal title to land. the provisions of the agrarian basic law article 4 paragraph 1 are related to article 21 which stipulates that only Indonesian citizens can have ownership rights and legal entities appointed by the government.

But all the research has been examined through the announcement, who can provide opportunities for parties who are concerned with the importance of advancing.

At the same time, the announcement in the form of an annual system was determined at least 30 days. Announcement of the land acquisition has been sporadically more than 60 days. consideration of the difference in the period of the announcement because systematic land registration is a mass land registration activity that covers many parcels of land in an area and involves many people, so the possibility of being known by the general public is greater than sporadic land registration activities that are individual with limited scope so that only 
those who are interested know.

Based on the

Presidential Decree Number 32 of 1979 , the requirement for a large number of conversions has ended since September 24, 1980, means that has been given time that is relatively reluctant to 20 years after the introduction of conversion provisions as a matter of which was governed in the Indonesian agrarian constitution, which is intended to end the remaining western rights over Indonesian land with all its characteristics that are not in accordance with Pancasila and the 1945 Constitution. Thus each western right can be converted in accordance with a predetermined period of time, if past that period the land rights will be under state control. then proof of land rights that appear after this period, the right holder is required to submit an application directly to the head of the land office, by completing the requirements referred to in government regulation number 24 of 1997 concerning land registration. henceforth will be processed as holders of legal rights to land. The enactment of the provisions on the conversion of land rights originating from western rights covers 2 conditions, namely;

a. Rights that can be directly converted,

b. Recognition of conversion / enforcement.

So at any time, it needs to be done in the form of legal ownership to the physical and legal nature of the law, through the mechanism which is intended to be made in law.

\section{Conversion of Druwe Desa rights into communal rights of indigenous peoples.}

The Druwe village should be converted to become a legal community that has similarities or resemblance to the rights of the village Druwe both regarding the subject of the right holder and the authority of the right holder. ${ }^{10}$

Minister of Agriculture Regulation / BPN Decree No. 10 YEAR 2016 PAY 33 (2) subjects of the community will be special people and the law and the poor people who are in particular.

Article 1 of the Government Regulation No. 38 of 1963 , people say that the village does not belong to the law. With no village designation as a legal subject that has owned the land in the past, there is an issue on the issue of land in the province. These permissions arose due to the fact that the village residents were in the law and belonged to the people in the land. In this way, there has

10 Article 1 Number 1 Ministerial Decree / Head of BPN No. 10 year 2016 about the determination of community communities on the law of the attitude and the people of the people who are in a special region. 
also been a legal vacuum in what is called a special law called a village in particular. With this legal vacuum the author believes that there will be a shift in ownership of the village to become the property of the individual. One with the next will be the confession of individual individuals who weaken the rights of allies.

This show that against costumary land right or druwe desa in Bali, if communal right from publik custom right in this case desa pakraman getting stonger, then individual right (krama desa) getting weaker, and vice versa.

Theory of Ter Haar known as baloon theory, or what was stated by Iman Sudiat, apllies to lands druwe desa in Bali, because land druwe desa, on one side land status are land druwe (belongs) pakraman village which has been admittedly existence by krama desa. But within national land law didn't obtain recognition right of ownership which owned individual or legal entity under provision goverment regulations which governs concerning on designation law entity which can have land right of ownership therefore if land regulations druwe desa in Bali continous so will be able to provide opportunitues for strengthening cerrtain customary law communities.

Based on provisions paragraph 2 (1) provisions conversion celarly shows regonition of costumary land or communal land of village which contained in the article termed with right to druwe dan druwe desa (communal land). With right recignition of druwe desa on UUPA, mean strengthening the positions of costumary land or village communal land beside existence indeed so strong in people's lives desa pakraman in Bali.

As a result of this provision comes the Presidential Decree Number 34 of 2003 concerning National Policy In The Land Sector. This President's decision on the principle of granting the authority to the government of district/city in the land sector. This is specified in paragraph 2 (1) and (2), about authority district/city in terms of settlement communal right regulated on paragraph 2 (1) letter $\mathrm{f}$.

As explained in the balloon theory from Ter Haar, which says that the stronger the communal rights, weaker the rights of individuals and vice versa. ${ }^{11}$

$$
\text { Definition communal }
$$
rights by using the term "ancient" is only owned by a tribe (clans/gens/stam), a union villages (dorperbond) or usually by a village to control the whole land in its environment. ${ }^{12}$

11 I Made Suasthawan Dharmayuda, op.cit , 2001, h.118.

12 Iman Sudyat, Hukum Adat Sketsa Asas, Liberty, Cetakan ke dua, Yogyakarta, 1981, page. 2 
Paragraph 1 (7) decide

"krama

pengempon/pengemong are krama village pakraman/krama banjar prakaman who have inner and outer bonds with khayangan which in the area and responsible for maintenance, treatment, and implementation of ceremonial activities in khayangan, publics are all of reception form religion which adopted by that society ${ }^{13}$

Paragraph 1 (4) Ministry of Agriculture Regulation in the Province of Bali No. 3/2003 determine :

Prakaman village are public unity of custom right in Province Bali that have a unity of tradition and manners association of life Hindu society, in a hereditary within bonding khayangan tiga atau khayangan desa which has a certain territory and own wealth accompanied by the right to manage their own household.

Mentioned in paragraph

5 (1) Minister of Agriculture Regulation / Head of the National Land Agency No. $5 / 1999$ stipulates that this research still has communal rights as referred to in article 2 does by regional government with to include the person concerned, as a follow up to this provision be taken out president decision No. 34 of

13 Bushar Muhamad, Asas-Asas Hukum Adat, Pradnya Paramita, Jakarta, 1978, page 11-12
2003 about the National Policy in the Field of Defense. Presidential Decree on the principle of giving authority to district / city governments in the field of land. This is specified in paragraph 2 (1) and (2). About authority district/city in terms of problem solving communal right regulated in paragraph 2 (1) letter f. Recognition of communal rights also be seen in goverment regulations No. 16 of 2004 dated 10 May 2004 about stewardship region. In paragraph 6 , determine policy about stewardship region held to :

a. A plot of land for which rights already exist but not yet registered;

b. State Land;

c. Communal land of society custom right according to provision applicable laws and regulations

As in the provisions paragraph 2 (1) conversion provisions clearly indicate recognition of customary land or village communal land which in the paragraph called the right to druwe and druwe desa (village land right). By acknowledging right to druwe desa in UUPA, means strengthen the position custom land or village communal land. In additions to existence is so strong in lives of society desa pakraman in Bali.

That communal rights as a technical juridical are inherent right as typical competence on custom right 
society, in the form of authority / power to manage and regulate the land as a whole with power of inward and outward behavior.

As referred to custom right, Paragraph 2 (3) Minister of Agriculture Regulation / Head of the National Land Agency No. 5/1999 determine that society of custom right are a group of people who are related by law because of equality residence or based on descent.

As specified in

Paragraph 1 (4) Regional Regulation No 3 of 2001 it is clear that desa pakraman is a customary law society. Because has been formulated on Paragraph 1 (4). ${ }^{14}$

Desa pakraman in Bali deeply related to concept $T r i$ Hita Karana, those are the three causes of happiness in living in the world if pay attention to three things that is : fisrt relationship between human and god, second relationship between human and fellow humans, third the relationship between humans and environment.

As quoted from the book of Ahmad Sodiki state that reality uniformity is a rejection of pluralism, different from the statement of Soepomo declare that concerning the uncertainty of custom law states that in the hands of a judge the legal protection is given through a decision. ${ }^{15}$

Aspects of protection for indigenous society need to get an important role from policy makers to be able to understand the sense of justice in the local society. Of some land druwe owned by desa pakraman consist of tanah laba pura, tanah pekarangan desan, and tanah ayahan desa. Only tanah laba pura who just got protection. While tanah pekarangan desan, and tanah ayahan desa haven't received legal protection.

Furthermore, the aspect of legal protection over the tanah laba pura can be seen from the number of the Minister of Home Affairs decision No : SK.556/DJA/1986. Concerning the appointment of pura (temple) as religious legal entities that can have ownership of land. so that desa druwe are more precisely converted into communal rights of indigenous society. Because the rights of desa druwe are rights that have a collective nature, who have similarities or semblance with the communal rights of indigenous peoples both regarding the subject of the holder of the right and the authority of the holder of the land rights as stated in regulation of the Minister of Spatial Administration /

15 A.Parlindungan . Pandangan kondisi pelaksanaan Undang-undang pokok agrarian. Bandung Alumni, 1986, page. 11 
National Land Agency No 10 of 2016 paragraph 3 (2). The community only has right to use and manage and cannot be separated from the obligations of the custom village.

\section{CONCLUSION}

Conversion of desa duwe rights to ownership according to paragraph 2 of the provisions on the conversion of the agrarian main law (UUPA) does not comply with the law, because between the rights of the desa druwe and the ownership rights do not have in samness or similarities both regarding the subject of the holder of the right to his land or the authority of the holder of the right so the conversion cannot be done. basically the conversion can be done if there are sameness or similarities between the old rights with the new rights that become the object, besides that it also refers to paragraph 9 (5) of Regional Regulation Province Bali No. 3 of 2001 about Pakraman Village which has been changed Regional Regulation Province Bali No. 3 of 2003 about Pakraman Village explain land ownership rights to the pakraman bali village cannot be certified in the personal name. As well regulation of the Minister of Spatial Administration / National Land Agency No 10 of 2016 paragraph 3 (2). The community only has right to use and manage and cannot be separated from the obligations of the custom village.

\section{REFERENCES}

\section{Book :}

Ali Achmad Chomzah, 2004, Hukum Agraria Pertanahan Indonesia, Prestasi Pustakaraya, Jakarta;

Anis Mashdurohatun, Intellectual Property Protection of Indigenous Peoples in Indonesia: Quo Vadis?, Sociological Jurisprudence Journal, Volume 3; Issue 1; 2020

A.Parlindungan, 1986, Pandangan kondisi pelaksanaan Undang-undang pokok agrarian, Alumni, Bandung;

Arba, 2017, Hukum Agraria indonesia, Sinar grafika, Jakarta ;

Bali Provincial Regulation No. 3/2001 which has been amended by Bali Provincial Regulation 2003 concerning Pakraman Village;

Boedi Harsono, 2008, Hukum Agraria Indonesia, Jambatan, Jakarta,

Bushar Muhamad, 1978, Asas-Asas Hukum Adat, Pradnya Paramita, Jakarta;

Decree of the Minister of Home Affairs Number SK.26 / DDA / 1970 of 1970 concerning Affirmation of Conversion;

Decree of the Minister of Agrarian Affairs and Spatial Planning / Head of the National Land Agency Number 276 / KEP-19.2 / X / 2017 
Regarding the Designation of Pakraman Village in Bali Province as the Subject of Common Land Rights (Communal) Rights over Land;

Decree of the Minister of Home Affairs Number SK / 556 / DJA / 1986 Regarding the Appointment of Temples as Religious Legal Entities That Can Have Property Rights;

I Gusti Ngurah Tahara Wiguna, 2009, Hak-hak Atas Tanah Pada Masa Bali Kuma Abad X-XI Masehi, Udayana University Press, Bali;

Iman Sudyat, 1981, Hukum Adat Sketsa Asas, Liberty, Cetakan ke dua, Yogyakarta;

Law of the Republic of Indonesia Number 5 of 1960 concerning Basic Regulations on Basic Agrarian Issues;

Minister of Agriculture and Agrarian Regulation No. 2 of 1962 Concerning Confirmation of Conversion and Registration of the Former Indonesian Rights to Land;

Republic of Indonesia Government Regulation Number 38 of 1963 Concerning the Appointment of Legal Entities that Can Have Property Rights on Land;

Regulation of the Minister of Agraria Number 2 of 1960 Concerning the Implementation of Basic Agrarian Law Provisions

Regulation of the Minister of Agraria Number 5 of 1960 concerning Addition to the Provisions of Regulation of the Minister of Agraria Number 2 of 1960;

Shidarta, 2009, Moralitas Profesi Hukum Suatu Tawaran Kerangka Berpikir, Refika Aditama, Bandung;

Ter Haar Bzn. 1950, Beginselen en stelsel van het Adatrecht, Griningen-Jakarta;

Regulation of the Minister of Agrarian Affairs and Spatial Planning / Head of the National Land Agency of the Republic of Indonesia Number 10 of 2016 concerning Procedures for Establishing Communal Rights in Land of Indigenous Peoples and Communities in Certain Regions (State Gazette of the Republic of Indonesia of 2016 Number 568; 